\title{
Establishing empirical correlation between sediment thickness and resonant frequency using HVSR for the Indo-Gangetic Plain
}

\author{
P. Anbazhagan*, A. Janarthana Boobalan and H. S. Shaivan \\ Department of Civil Engineering, Indian Institute of Science, Bengaluru 560 012, India
}

In this study, microtremor survey was carried out at 31 locations of Indo-Gangetic Plains (IGP) using a pair of portable three-component short-period seismometers (Guralp CMG-6T-1) and Kelunji Echo Pro digital data acquisition system. The acquired raw data was processed to obtain the average $H / V$ ratio of the ambient vibration spectrum. The frequency corresponding to the first peak of the average $H / V$ spectrum was taken as resonant frequency of that particular site. A comparison was made between the resonant frequencies obtained from peak of the $H / V$ spectrum with those obtained using the source-receiver function from previously published work. The results were in good agreement with each other. An empirical equation has been established for the IGP by relating resonance frequency with sediment thickness, using available data from nearby boreholes drilled up to bedrock. The empirical equation was compared with other equations available for deep soil sites, i.e. sites with soil thickness more than $750 \mathrm{~m}$. Further, a combined equation was developed for the digitized data taken from previously published works of deep soil sites. Finally, it has been found that the regionspecific equation gives better estimate of sediment thickness than the other empirical equations; but in absence of such a region-specific equation, the proposed combined equation can be used for a quick preliminary assessment of sediment thickness of a deep soil region.

Keywords: HVSR method, Indo-Gangetic plains, microtremor, resonant frequency, sediment thickness.

DYNAMIC properties of subsurface layers are one of the most critical factors which influence the ground motion characteristics. The seismic waveform at a particular site is almost similar for any earthquake recording because of the influence of the dynamic characteristics of the subsurface layers on the ground motion. In this regard, the IndoGangetic Plains (IGP) can be considered to be of particular importance because of its association with the tectonically active Himalayan region and the deep sediments deposited over a long period of time. The deep sediments

\footnotetext{
*For correspondence. (e-mail: anbazhagan@iisc.ac.in)
}

present in the IGP can cause local site amplification, and in extreme cases may induce a condition of 'resonance' at those sites where the natural frequency of the structure matches with that of the surface ground motion. Also, the deep loose sediments are prone to liquefaction due to seismic events, which could have extensive damage on the structures built in and around the IGP. Hence, an estimation of sediment thickness would be helpful in the preliminary assessment of the dynamic characteristics of the subsurface soil in the IGP.

It has been found that the seismic signals from a hard site are uniform throughout all frequencies, but for a soft soil site the signal is amplified at its resonant frequency, which is a function of soil type, bedrock configuration, etc. Hence, if the source and the path effects were to be removed from the spectra of the signal, then a flat response would be available at a hard rock site, and a maximum amplitude at resonant frequency for a soft soil site. Researchers have used different methods to remove source and path effects ${ }^{1-9}$. A simple method was introduced by Nakamura ${ }^{10}$ known as the $H / V$ ratio method. This method could be used to estimate the site effects, by measuring only the ambient vibrations on the ground surface using single instrument. The site response estimate is obtained by dividing the mean of horizontal component by the vertical component of the noise spectrum. It was observed that the horizontal component of ground motion showed larger amplifications in comparison with the vertical component at the resonant frequency. Hence, horizontal to vertical spectral ratio (HVSR) showed a peak at that particular frequency which corresponded well to the resonant frequency of the soil. This technique has been used worldwide as a cost-effective tool to estimate the resonant frequency of the site by determining the HVSR at a single-station measurement ${ }^{11}$.

Several studies are available regarding the estimation of $H / V$ ratio from the earthquakes and microtremor of various sedimentary plains. Theoretical explanation about $H / V$ ratio method is available in the literature, e.g. refs $12,13 . H / V$ Ratio method finds its application in estimating wave amplification, site effect evaluation, microzonation studies, sediment depth estimation, and in liquefaction studies $^{13-22}$. Some microtremor studies have also been done in India. Dinesh et al. ${ }^{23}$ used the microtremor $H / V$ 
ratio measurements to establish an empirical correlation between sediment thickness and resonant frequency for Bangalore city. Sukumaran et al. ${ }^{24}$ used the microtremor data for calculating HVSR and to compute the approximate thickness Quaternary sediment and late Quaternaryearly Tertiary topography for the part of lower reaches of Narmada valley. Natarajan and Rajendran ${ }^{25,26}$ used the HVSR technique to estimate site response of Kachchh rift basin over the meizoseismal area of the 2001, $M_{w} 7.6$, Bhuj (NW India) earthquake, and determined that site effects were not significant during the 2001 earthquake damage observed in Bhuj. Recently, Sant et al. ${ }^{27}$ have used the microtremor method for subsurface profiling along Banni Plains and bounding faults in Kachchh, Western India; and Joshi et al. ${ }^{28}$ have used the microtremor method for subsurface profiling of granite pluton in southern Aravalli, Gujarat, India. But, no such experimental study has been conducted for the Indo-Gangetic region. Hence, the present study was taken up to examine the application of Nakamura technique to estimate the sediment depth in Indo-Gangetic plain, and propose an empirical correlation based on the available subsoil characteristics close to microtremor recording stations. Also, other deep site soil thickness correlations developed globally have been examined for their applicability in the IGP.

\section{Study area}

The IGP is one of the deepest sedimentary plains in the world. The plain is composed of alluvium deposited by major rivers like the Ganga, Yamuna, Indus, Brahmaputra and their tributaries. In recent years, there is renewed interest in identifying the subsoil characteristics and dynamic properties of the plains because they are prone to earthquake-induced potential hazards, since IGP is tectonically active. IGP is located to the south of subHimalaya and extends up to Aravalli in the west, Satpura and Vindhyan ranges in the south. The origin of IndoGangetic basin has been subject of interest since the early 1900 s when Burrard ${ }^{29}$ published a paper on the origin of Indo-Gangetic trough or Himalayan fore-deep. Sedimentary deposits have been interrupted by longitudinal and transverse faults, thereby generating an uneven configuration of subsurface topography consisting of alternating ridges and depressions. Figure 1 shows the geology of the study area marked along with microtremor survey locations.

Geological and geophysical information about IGP shows distinctive subsurface features. The metamorphic basement of IGP is characterized by a number of ridges and faults over which thick sedimentary covers are present $^{30}$. From south, important ridges are DelhiHaridwar ridge, Faizabad ridge, a poorly developed Mirzapur-Ghazipur ridge and Monghyr-Saharsa ridge; while Raxaul, Bahraich and Puranpur ridge exists in northern part of the basin. The most important faults are Moradabad faults, Bareilly faults, Lucknow faults, Patna faults and the Malda faults. These faults are considered to be tectonically active, with 1934 and 1988 Bihar-Nepal border earthquakes being associated with them. Other major earthquakes have also occurred from 1965 to 1995 in $\mathrm{IGP}^{31}$. Earthquakes within IGP or those in the vicinity of the region can cause considerable damage to structures in the IGP due to local site amplification because of the thick sediment deposit.

Information about the sediment thickness of IGP can be acquired through studies such as gravity, seismic and deep drilling for oil exploration by the Oil and Natural Gas Commission $^{32}$. Exploratory wells beneath the Ganga alluvium $^{33}$ have revealed that the depth of Neogene (Siwalik) sediments varies from 500 to $1500 \mathrm{~m}$. In northern part of the basin, deep borehole studies of Shahjahanpur and Bilaspur shows the presence of $4.1 \mathrm{~km}$ thick recent alluvial sediments overlying the molassic formations of the Siwalik group ${ }^{33}$. Further south, the thickness of sediments decreased to about $1.2 \mathrm{~km}$ at Lucknow and 500-600 $\mathrm{m}$ at Kanpur. The comparatively thin sediment thickness in Kanpur and Lucknow than that in Shahjahanpur and Bilaspur is due to the presence of the Faizabad ridge ${ }^{34}$. Sudden increase in basement depth to more than $2.5 \mathrm{~km}$ within a profile distance of $20 \mathrm{~km}$ was observed in Lucknow which could be attributed to the Lucknow fault ${ }^{35}$. The other notable feature seen is the sudden deepening of the basement depth at Sandilain comparison to Kanpur and Lucknow by more than $1.5 \mathrm{~km}$ (ref. 34). The Bundelkhand massif exposed at the southern end of the basin was detected with sediment thickness of 250-300 $\mathrm{m}$ (ref. 35).

\section{Microtremor experiments}

Microtremor measurements were carried out at 31 locations of IGP using a pair of portable three-component

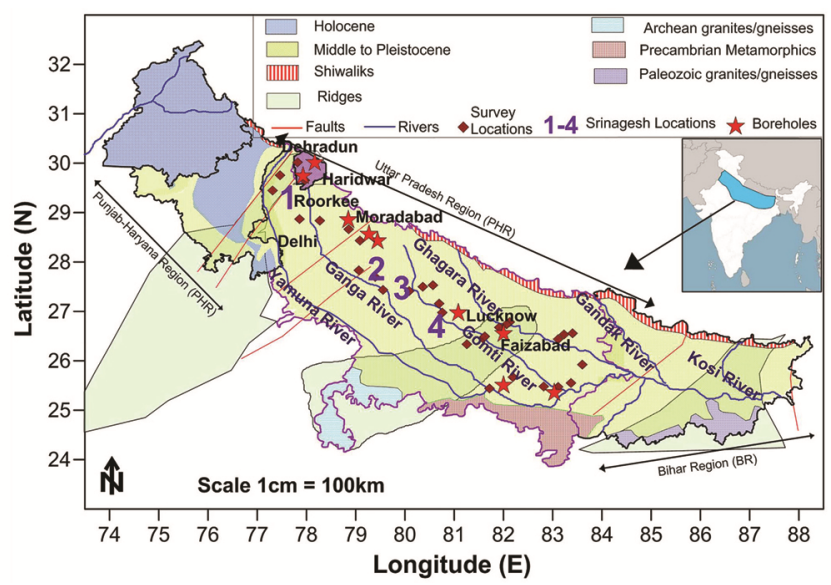

Figure 1. Study area map showing Indo-Gangetic basin with lithology. 
Table 1. HVSR resonant frequency of survey locations along with reliability parameters

\begin{tabular}{|c|c|c|c|c|c|c|c|}
\hline Location & $\begin{array}{l}\text { Latitude } \\
\qquad\left({ }^{\circ} \mathrm{N}\right)\end{array}$ & $\begin{array}{l}\text { Longitude } \\
\qquad\left({ }^{\circ} \mathrm{E}\right)\end{array}$ & $\begin{array}{c}\text { Number of } \\
\text { windows }\left(n_{w}\right)\end{array}$ & $\begin{array}{c}\text { Length of } \\
\text { windows }\left(l_{w}\right)\end{array}$ & $\begin{array}{c}\text { Resonant } \\
\text { frequency }(\mathrm{Hz})\end{array}$ & $\begin{array}{l}\text { Number of windows } \\
\text { and cycles }\left(\mathrm{n}_{\mathrm{c}}\right)\end{array}$ & $\begin{array}{l}\text { Calculated sediment } \\
\text { thickness from } \\
\text { eq. (2) }(\mathrm{m})\end{array}$ \\
\hline Hussain Ganj Kalan & 26.44 & 81.68 & 27 & 60 & 0.18 & 291.6 & 765.44 \\
\hline Allahabad & 25.43 & 81.81 & 9 & 60 & 0.39 & 210.6 & 448.97 \\
\hline Dherahi & 25.52 & 83.00 & 14 & 60 & 0.91 & 764.4 & 250.21 \\
\hline Sata Hariya & 25.66 & 82.25 & 17 & 60 & 0.22 & 224.4 & 666.47 \\
\hline Faizabad I & 26.77 & 82.19 & 17 & 60 & 0.37 & 377.4 & 465.58 \\
\hline Faizabad II & 26.72 & 82.13 & 22 & 60 & 0.17 & 224.4 & 796.23 \\
\hline Maupara & 25.54 & 83.35 & 14 & 60 & 0.32 & 268.8 & 514.63 \\
\hline Mau & 25.91 & 83.56 & 20 & 60 & 0.171 & 205.2 & 793.02 \\
\hline Benwapur & 26.54 & 83.38 & 18 & 60 & 0.32 & 345.6 & 514.63 \\
\hline Bankati Bujurg & 26.52 & 83.22 & 13 & 60 & 0.44 & 343.2 & 413.11 \\
\hline Saneha & 26.42 & 83.11 & 20 & 60 & 0.2 & 240 & 711.77 \\
\hline Alinagar & 26.48 & 81.72 & 16 & 60 & 0.385 & 369.6 & 452.98 \\
\hline Sijni & 26.33 & 81.39 & 19 & 60 & 0.206 & 234.8 & 697.40 \\
\hline Sharakpur & 26.96 & 80.92 & 16 & 60 & 0.33 & 316.8 & 503.82 \\
\hline Biswan & 27.48 & 80.97 & 14 & 60 & 0.25 & 210 & 610.20 \\
\hline Gopalpur Rampur & 27.23 & 80.68 & 21 & 60 & 0.18 & 226.8 & 765.44 \\
\hline Adora & 27.66 & 80.49 & 15 & 60 & 0.31 & 279 & 526.03 \\
\hline Bharayal & 27.39 & 80.29 & 25 & 60 & 0.24 & 360 & 627.63 \\
\hline Sanjhara & 27.42 & 79.8 & 21 & 60 & 0.18 & 226.8 & 765.44 \\
\hline Katiuli & 27.68 & 79.65 & 18 & 60 & 0.2 & 216 & 711.77 \\
\hline Usawan & 27.81 & 79.34 & 16 & 60 & 0.21 & 201.6 & 688.21 \\
\hline Rsoola & 28.23 & 79.13 & 19 & 60 & 0.17 & 1960.8 & 796.23 \\
\hline Karanpur & 28.81 & 78.6 & 19 & 60 & 0.9 & 1026 & 252.13 \\
\hline Agwanpur & 29 & 78 & 16 & 60 & 3.31 & 3177.6 & 102.65 \\
\hline Khalilpur & 29.62 & 78.32 & 8 & 60 & 0.18 & 211.2 & 765.44 \\
\hline Loha Patti Bhagirnath & 28.64 & 79.15 & 19 & 60 & 1.3 & 1482 & 195.63 \\
\hline Haridwar & 29.99 & 78.18 & 22 & 60 & 0.35 & 264 & 483.77 \\
\hline Dahyaki & 29.73 & 77.85 & 12 & 60 & 0.12 & 1044 & 1012.55 \\
\hline Muzaffarnagar & 29.42 & 77.71 & 18 & 60 & 0.4 & 226 & 441.19 \\
\hline Samogara & 25.47 & 82.83 & 10 & 60 & 0.95 & 570 & 242.90 \\
\hline Rasoolpur & 26.66 & 81.99 & 19 & 60 & 0.23 & 262.2 & 646.34 \\
\hline
\end{tabular}

short-period seismometers (Guralp CMG-6T-1) having a natural period of $1 \mathrm{sec}$ and Kelunji EchoPro digital acquisition system. The microtremor data was recorded at 100 samples per second.The sensor used has the capability of measuring frequency in the range between 1 and $50 \mathrm{~Hz}$, and has the same characteristics in all its three axes. Out of 31 locations, 9 sites were very close to sites of borehole drilling that had reached bed rock, i.e. sites with a precisely known thickness of sedimentary cover. Location of microtremor survey locations and drilled borehole sites are shown in Figure 1.

The complete data processing was carried out using Geopsy software. For each station, the time-series of the record was divided into a window of $60 \mathrm{sec}$ duration. Each window was base-line corrected for anomalous trends, tapered with a 5\% cosine window, and band-pass filtered. The Fourier amplitude spectra of each selected window were computed and smoothened using Konno and $\mathrm{Ohmachi}^{36}$ with a smoothing constant value of 40 . Then, the average spectral ratio of the horizontal to vertical component (i.e. $H / V$ ) in each window was calculated from the equation ${ }^{16}$

$$
H / V=\sqrt{\left(F_{\mathrm{NS}}^{2}+F_{\mathrm{EW}}^{2}\right) / 2 F_{\mathrm{V}}^{2}} \text {. }
$$

Here, $F_{\mathrm{NS}}, F_{\mathrm{EW}}$ and $F_{\mathrm{V}}$ are the Fourier amplitude spectra in the north-south (NS), east-west (EW) and vertical (V) direction respectively. The average of the $H / V$ spectral ratios obtained for each window is taken as the final $H / V$ ratio of the particular survey location, and the frequency corresponding to the first peak of the $H / V$ spectrum plot is taken as the resonant frequency of the site $e^{12,37}$.

HVSR values of 31 stations along with its geographical position are presented in Table 1 with the corresponding parameters that help to prove the reliability of the curve obtained in this study. Using uniform window length of $60 \mathrm{sec}$ and anti-trigger algorithm, number of windows ranging from 8 to 27 was obtained. The obtained resonant frequency was greater than $0.12 \mathrm{~Hz}$ in all the cases. Standard deviation of resonant frequency fell within the recommended value, indicating the low scattering of frequency values from mean position. Also, the number of cycles was greater than 200 proving that a large number of cycles and windows were used for producing HVSR plots. Every plot thus produced was strictly within the prescribed limit showing good reliability as per SESAME $^{37}$ guidelines. Thirty-one $H / V$ spectrum plots are shown in Figure 2. An overall similarity in shape of the resonant frequency curves was observed with most of 

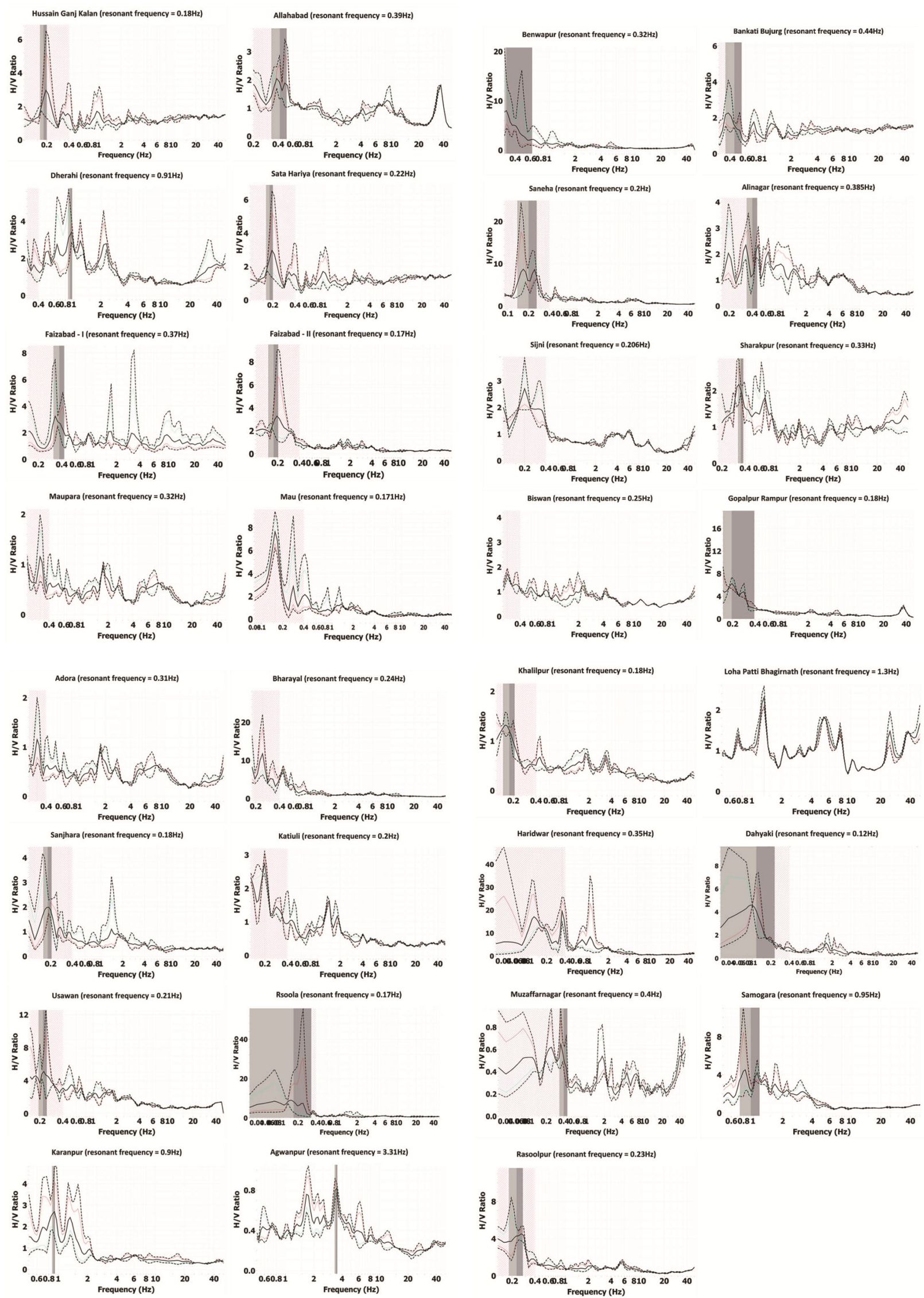

Figure 2. $H / V$ spectrum plots along with resonant frequency values for all the survey locations carried out in the Indo-Gangetic Plains. 
Table 2. Summary of the previously published empirical equations for the estimation of sediment thickness using resonant frequency from microtremor measurements

\begin{tabular}{|c|c|c|c|c|c|}
\hline Author & $\begin{array}{l}\text { Empirical } \\
\text { relationship }\end{array}$ & Study area & Comparison & $\begin{array}{l}\text { Geology of } \\
\text { the area }\end{array}$ & $\begin{array}{l}\text { ment thickness } \\
\text { covered }\end{array}$ \\
\hline Seht and Wohlenberg ${ }^{14}$ & $H=96 f_{r}^{-1.388}$ & $\begin{array}{l}\text { Western Lower Rhine } \\
\text { Embayment in Germany }\end{array}$ & $\begin{array}{l}34 \text { boreholes with } \\
\text { data from } 102 \\
\text { microtremor measurements }\end{array}$ & $\begin{array}{l}\text { Sedimentary cover } \\
\text { with approximate } \\
1000 \mathrm{~m} \text { thickness }\end{array}$ & $15-1257 \mathrm{~m}$ \\
\hline Delgado et al. ${ }^{16}$ & $H=55.64 f_{r}^{-1.268}$ & Bajo Segura Basin, Spain & $\begin{array}{l}33 \text { microtremor surveys } \\
\text { with } 23 \text { borehole } \\
\text { locations }\end{array}$ & Sedimentary & $3.8-46.1 \mathrm{~m}$ \\
\hline Parolai et al. ${ }^{39}$ & $H=108 f_{r}^{-1.551}$ & Cologne area, Germany & $\begin{array}{l}32 \text { boreholes with } 337 \text { data } \\
\text { from seismic stations }\end{array}$ & $\begin{array}{l}\text { Sediment thickness } \\
\text { varying from } \\
100 \text { to } 500 \mathrm{~m}\end{array}$ & $10-401.6 \mathrm{~m}$ \\
\hline Hinzen et $a l .{ }^{40}$ & $H=137 f_{r}^{-1.19}$ & $\begin{array}{l}\text { Lower Rhine Embayment, } \\
\text { Germany }\end{array}$ & $\begin{array}{l}50 \text { microtremor survey } \\
\text { points with lithology data }\end{array}$ & $\begin{array}{l}\text { Sedimentary cover } \\
\text { with approximate } \\
1000 \mathrm{~m} \text { thickness }\end{array}$ & $\begin{array}{l}60-1250 \mathrm{~m} \\
\text { (medium } \\
\text { thickness } \\
\text { of } 600 \mathrm{~m} \text { ) }\end{array}$ \\
\hline Birgören et al..$^{41}$ & $H=151 f_{r}^{-1.531}$ & Istanbul & $\begin{array}{l}15 \text { microtremor survey at } \\
\text { borehole locations }\end{array}$ & Sedimentary & $20-366 \mathrm{~m}$ \\
\hline Özalaybey et $a l^{42}$ & $H=141 f_{r}^{-1.27}$ & Izmit Bay area, Turkey & $\begin{array}{l}239 \text { microtremor survey } \\
\text { with } 405 \text { point gravity } \\
\text { measurements }\end{array}$ & $\begin{array}{l}\text { Sedimentary cover } \\
\text { ranging from } \\
\text { thickness of } 750 \mathrm{~m} \\
\text { to } 1200 \mathrm{~m} \text { thickness }\end{array}$ & $60-1120 \mathrm{~m}$ \\
\hline Paudyal et al..$^{21}$ & $H=146 f_{r}^{-1.2079}$ & Kathmandu basin & $\begin{array}{l}172 \text { microtremor survey } \\
\text { with } 2 \text { Boreholes } \\
\text { (taken from previous } \\
\text { study) }\end{array}$ & $\begin{array}{l}\text { Lacustrine sediments } \\
\text { with varying } \\
\text { sediment thickness } \\
\text { within a few meter }\end{array}$ & $\begin{array}{l}\text { Max.357 m } \\
\text { thickness }\end{array}$ \\
\hline Biswas et al. ${ }^{42}$ & $H=160.9 f_{r}^{-1.459}$ & Shillong, Northeast India & $\begin{array}{l}70 \text { microtremor surveys } \\
\text { with available borehole } \\
\text { lithology data }\end{array}$ & Sedimentary & $10-200 \mathrm{~m}$ \\
\hline Del Monaco et al. $^{44}$ & $H=129.3 f_{r}^{-1.06}$ & Western L'Aquila plain & $\begin{array}{l}790 \text { microtremor surveys } \\
\text { with available borehole } \\
\text { data }\end{array}$ & $\begin{array}{l}\text { Sedimentary layer with } \\
100 \mathrm{~m} \text { thickness }\end{array}$ & $10-200 \mathrm{~m}$ \\
\hline Khan and $\mathrm{Khan}^{45}$ & $H=134 f_{r}^{-1.23}$ & Islamabad city, Pakistan & $\begin{array}{l}81 \text { microtremor surveys in } \\
\text { comparison with already } \\
\text { published data }\end{array}$ & $\begin{array}{l}\text { Sediment thickness } \\
\text { upto } 100 \mathrm{~m}\end{array}$ & $4-138 \mathrm{~m}$ \\
\hline
\end{tabular}

them falling in the range $0.17-0.44 \mathrm{~Hz}$. Further analysis of curves showed that HVSR along the edge of the basin showed almost a flat response with small peak at the higher frequency while those inside the basin showed a clear peak response at lower frequency. An increase in resonance frequency was observed in northern part while in southern part of the basin low resonance frequency was observed ranging from 0.18 to $0.33 \mathrm{~Hz}$.

\section{Results and discussion}

\section{Comparison of resonance frequency}

Srinagesh et $a l .^{38}$ have observed the predominant frequency using source-receiver function for 8 different sites located in central part of Indo-Gangetic basin. All these sites were located on soft alluvial sediments. Out of these 8 stations, 4 of them were far from our survey locations, and hence the remaining 4 sites were used for our comparison purpose. The coordinates of these 4 sites have been marked as numbers $1-4$ in Figure 1; the 4 sites are Roorkee - 1, Shahjahanpur - 2, Hardoi - 3 and Sandila - 4. It can also be observed from Figure 1 that the Srinagesh et $a l .{ }^{38}$ locations belong to the central part of the IGP, but the 31 locations of the present study are spread throughout the entire IGP region.

Figure 3 shows the comparison of resonant frequency measured in the present study with Srinagesh et al. ${ }^{38}$. It can be observed that the results show good agreement between both the methods. However, the slight difference in values may be attributed to the local geology of the survey locations, and the distance between Srinagesh et $a l .{ }^{38}$ and the present study survey locations. Although 
both the methods differ in certain fundamental ways regarding assumption of source, path and site effects, they yielded similar prediction of resonant frequency.

\section{Relating resonance frequency with sediment thickness}

The inverse proportion relationship that exists between the main resonance frequency of a soil and its thickness is well known in the field of seismic soil response. The inverse relationship is of the form ${ }^{16}$

$$
H=a\left(f_{r}^{-b}\right)
$$

Several researchers have carried out correlation studies between $H / V$ spectral ratio peak frequencies and overburden thickness cover, aided by available borehole lithology data. Seht and Wohlenberg ${ }^{14}$, Delgado et al. ${ }^{16}$ and Parolai et $a l .{ }^{39}$ were the first to study the relationship between resonant frequency and the sediment thickness. Other important studies relating to sediment thickness with resonant frequency are in refs $11,21,22,39-45$. The empirical equations developed by previous researchers are given in Table 2 .

Various authors have developed empirical equations based on $1: 1$ comparison of survey location with available borehole data ${ }^{14,16,39,41,43-45}$. Seht and Wohlenberg ${ }^{14}$ have studied both the parameters (i.e. sediment thickness and resonant frequency) and demonstrated that it is possible to establish a direct functional relationship between them despite not knowing the shear wave velocity $\left(V_{\mathrm{s}}\right)$.

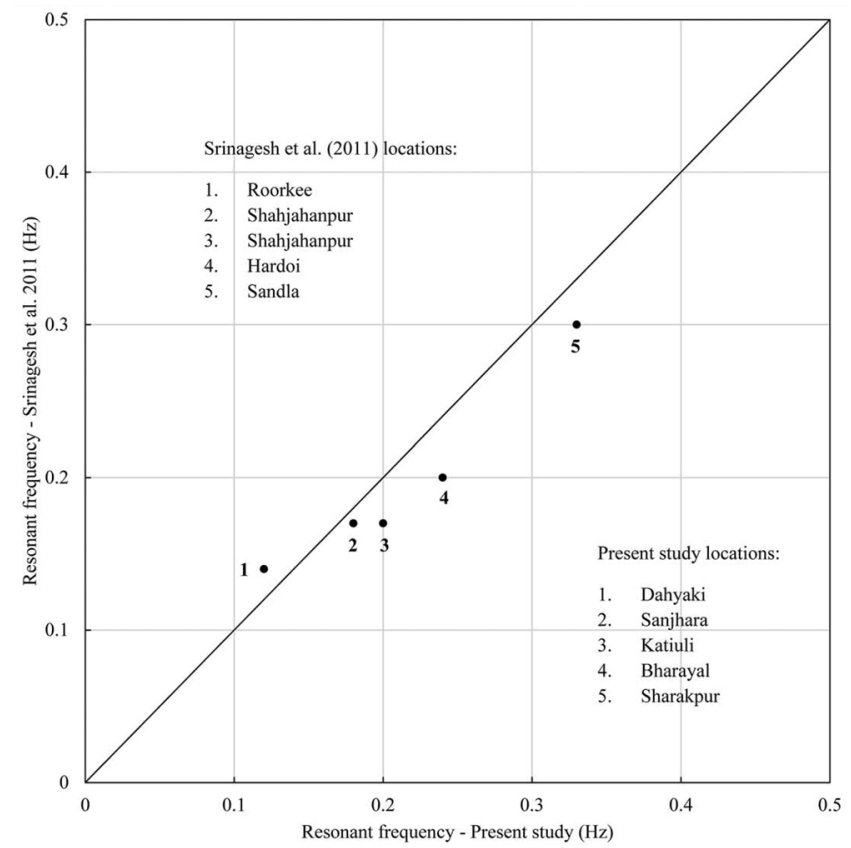

Figure 3. Comparison of resonant frequency from present study with Srinagesh et al. ${ }^{38}$.
They estimated the value of $a$ and $b$ and proposed an empirical relationship (eq. (3)) between the fundamental resonant frequency $\left(f_{r}\right)$ and the thickness of soft sediment cover (h) (quaternary sediments), based on 34 boreholes ranging in depth from 15 to $1257 \mathrm{~m}$ and data from 102 seismic stations. Hinzen et al. ${ }^{40}$ established an empirical equation (eq. (4)) based on 50 HVSR measurements with geological profiles from four boreholes which included stratigraphic information from 400 and $1000 \mathrm{~m}$ deep boreholes. Özalaybey et $a l .{ }^{42}$ have obtained regression relationship (eq. (5)) based on comparison between 239 microtremor surveys with 405-point gravity measurements. For this, the resonant frequency values were selected using the sites where the HVSR curves showed welldefined spectral peaks with amplitude greater than 3.5 and matching with gravimetric survey. This selection resulted in 47 corresponding resonant frequency values and their sediment thickness values have been derived from the gravimetric bedrock depth map. Out of the previous empirical equations developed for different regions with various soil sediment thicknesses, few authors ${ }^{14,40,42}$ have developed equations for sites with deep soil deposits having sedimentary thickness up to $1000 \mathrm{~m}$, while most of them have developed for shallow basin $\operatorname{data}^{11,21,22,39,41,43-45}$. Since the IGP has deep sedimentary cover ranging from 0.5 to $4 \mathrm{~km}$ (ref. 38), these three equations could possibly be used in estimation of sediment thickness for this region.

Using our observed values of $f_{r}$ from the peak in the $H / V$ spectral ratio and the sediment thickness cover data from nine nearby borehole locations, a regression fit of (1) was performed and the following equation was obtained

$$
H=234.45\left(f_{r}^{-0.69}\right) .
$$

Figure 4 shows the plot of sediment thickness with the resonant frequency, along with the fitted power equation. This equation has a good $R^{2}$ value of 0.8865 . The equation was obtained by nonlinear regression analysis of the data to fit a power function, by using the curve fitting tool in Matlab. It shows a decreasing trend of sediment thickness with an increase in frequency. This is quite expected as $H / V$ spectral ratios give rise to peaks at higher frequencies for sites where the bedrock becomes shallower. Further, sediment thickness for all the sites was calculated using the derived equation, and also with the three other applicable relationships developed earlier ${ }^{14,40,42}$. The calculated sediment thickness values have been compared to check the agreement of the present study with previous relationships. The three other applicable relationships are

$$
\begin{aligned}
& H=96\left(f_{r}^{-1.388}\right)(\text { ref. } 4), \\
& H=137\left(f_{r}^{-1.19}\right)(\text { ref. 40), }
\end{aligned}
$$




$$
H=141\left(f_{r}^{-1.27}\right)(\text { ref. } 42) \text {. }
$$

Figure 5 shows the comparison of residuals between the developed equation and the other three deep soil site equations. It illustrates the variation of error value in the estimation of sediment thickness with frequency. It can be observed that at lower frequencies $(0.15-0.3 \mathrm{~Hz})$, the error involved in the estimation of sediment thickness from the three empirical equations is very high, up to $500 \mathrm{~m}$. Equation given by Hinzen et al. ${ }^{40}$ performs better

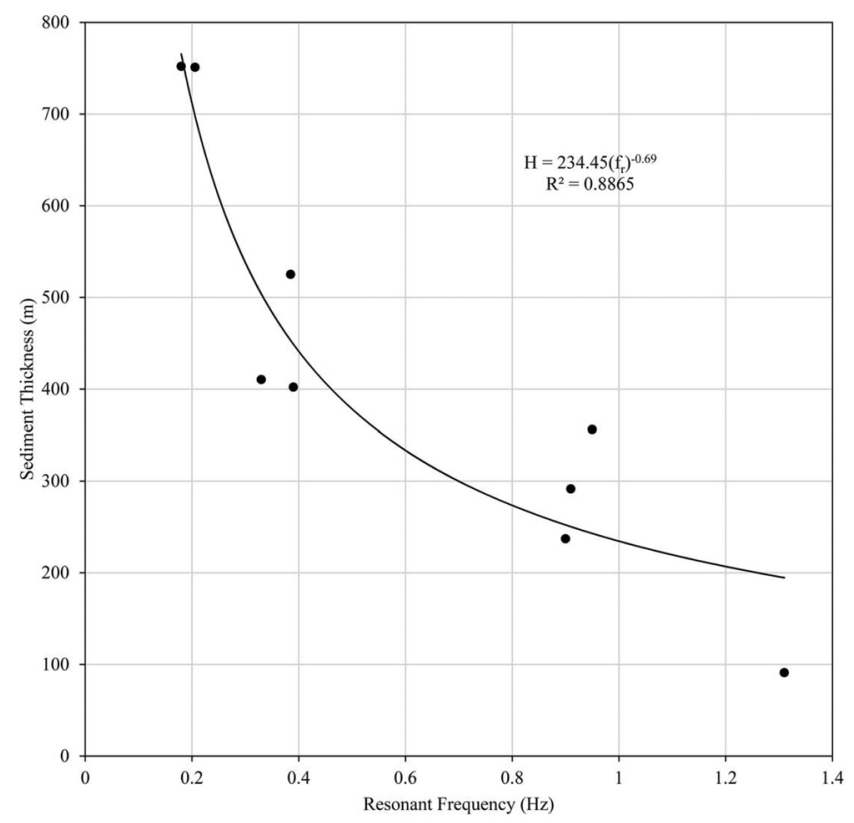

Figure 4. Empirical correlation established between resonan frequency obtained from the present study and the sediment thickness obtained from borelog data.

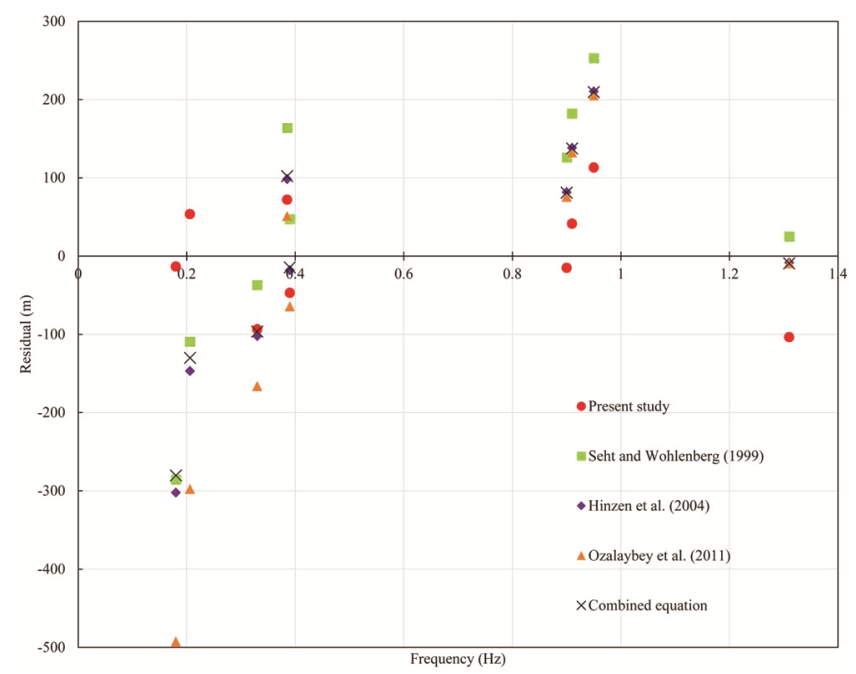

Figure 5. Comparison of residuals in estimation of sediment thickness using previously published equations for deep soft soil sites with the present experimental data. than the other two equations in predicting the sediment thickness for IGP. It has low magnitude errors in both the low frequency and high frequency ranges. Equation given by Seht and Wohlenberg ${ }^{14}$ performs the worst for this particular region. Although the equation follows the general trend as the other two equations, the error associated with it is very high for the entire frequency range. Equation developed by Özalaybey et al. ${ }^{42}$ gives the highest error for $0.18 \mathrm{~Hz}$, but thereafter it performs the same as the equation given by Hinzen et $a l .^{40}$. However, the developed empirical equation performs the best, except at $1.3 \mathrm{~Hz}$, among all these equations. Thus, it can be inferred that none of the previously published equations can satisfactorily estimate the sediment thickness of the IGP implying that for accurate estimations of the sediment thickness, the region-specific equation has to be used.

Figure 6 shows the plot of combined equation (eq. (6)) which has been developed by regression analysis by using the data available from the aforementioned deep soil studies and also by including the data from the present study.

$$
H=137.88\left(f_{r}^{-1.174}\right) .
$$

The sediment thickness and resonant frequency data was digitized $^{14,40,42}$. By combining this data with that of the present study, the combined equation has been developed which has $R^{2}=0.8835$. It is proposed to use the combined equation for estimation of sediment thickness when region-specific equation is not available. This equation has been developed so as to reduce the error in the estimation of sediment thickness which is evident in Figure 6. With the inclusion of the data from the present study to the previously published studies of deep soil sites, it can be observed that the combined equation performs better than the previously published equations; although the

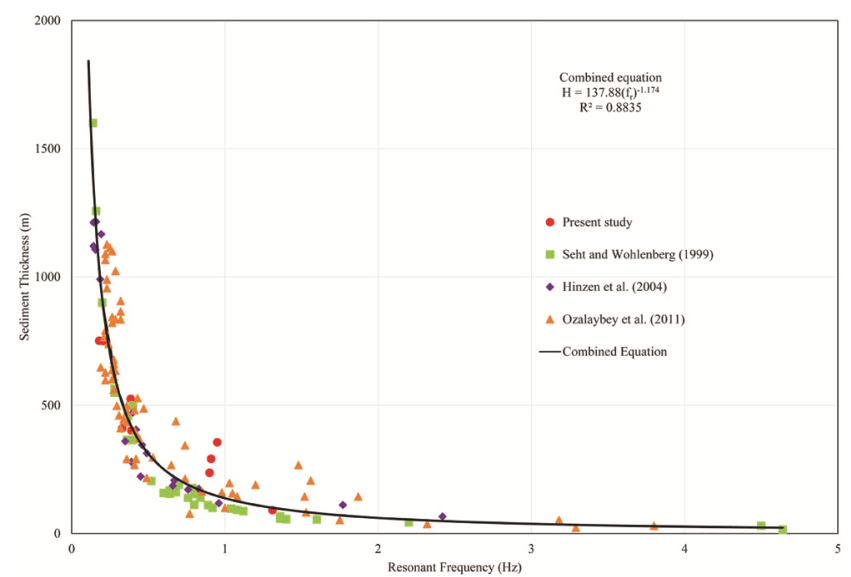

Figure 6. Plot of combined equation developed by using the data from previously published deep soil site studies along with the data from the present study. 
data from the present study added to the combined data is only $7 \%$. Hence, based on these observations and results, this combined equation can be used for a preliminary estimation of sediment thickness for any other deep soil site, when no other such correlations are available for that region.

Figure 7 shows the plot of three previously published deep soil site equations, the empirical equation obtained in this study and also the combined equation developed in this study, on a log-log scale. On comparing the equations, it can be observed that the three previously published equations overpredict the sediment thickness for low frequency and underpredict for high frequency. However, the magnitude of under prediction or overprediction is greater by Seht and Wohlenberg ${ }^{14}$ equation compared to the other two equations. Özalaybey et $a l^{42}$ have used sediment thickness obtained from gravimetric bedrock mapping to correlate with resonant frequency. They have not compared the sediment thickness with any bore $\log$, and they have also concluded that the absolute basin depths may vary within $\pm 30 \%$ of a given depth value. However, in the present study only reliable bore log data were used for developing the empirical correlation between sediment thickness and resonant frequency. Even though few locations out of the 31 survey locations had low resonant frequency values for example Dahyaki $-0.12 \mathrm{~Hz}$, reliable bore $\log$ data were not available for such locations. Perhaps, this may be the reason why the developed equation underpredicts at lower frequency whereas the previously published equations overpredict at the same frequency range, which is clearly evident from Figure 7 . Therefore, it has be kept in mind that the equation was developed with sediment thickness data until $750 \mathrm{~m}$ depth and using the equation beyond this limit may result in erroneous prediction of sediment thickness. In this regard, future studies can be taken up at particular locations in the IGP where reliable bore logs

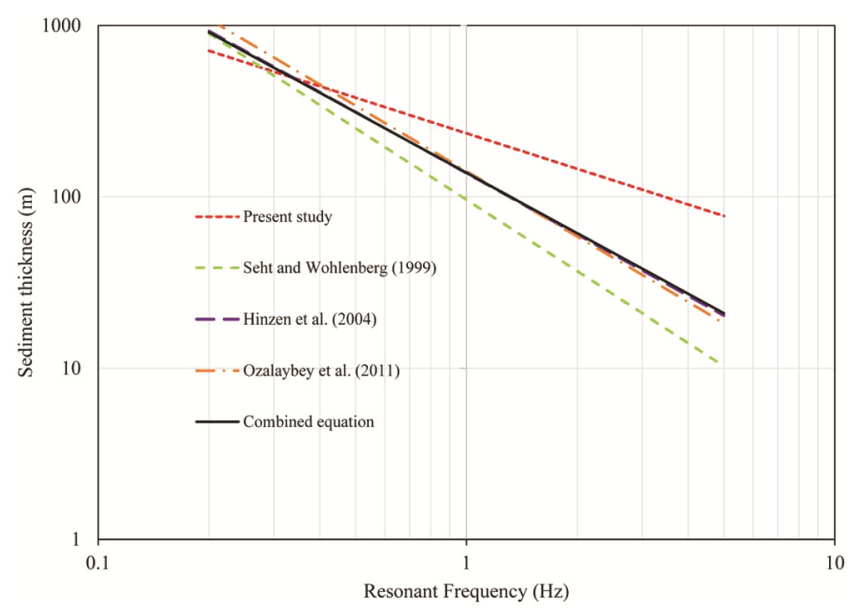

Figure 7. Plot of 4 empirical equations available for estimation of sediment thickness of deep soft soil sites and the combined equation developed after regression analysis. are available for sediment thickness greater than $750 \mathrm{~m}$, to further improve the applicability of developed empirical correlation in the present study.

\section{Conclusion}

The present study is the first attempt to relate sediment thickness of selected sites in the IGP with resonant frequency based on Nakamura technique. Microtremor measurements were carried out in 31 locations of IGP. Out of the 31 locations, 9 surveys were close to boreholes drilled up to bedrock. The following conclusions can be drawn from the study:

(1) The measured resonance frequency varies from 0.12 to $3.31 \mathrm{~Hz}$. An overall similarity in shape of the resonant frequency curves was observed with most of them falling in the range $0.17-0.44 \mathrm{~Hz}$. Further analysis of the curves indicated that the HVSR along the edge of the basin showed almost a flat response with small peak at the higher frequency while those inside the basin showed a clear peak response at lower frequency. An increase in resonance frequency with low amplification was observed towards north direction while in southern basin low resonance frequency with higher amplification was observed.

(2) Comparison of resonance frequency estimated from Nakamura technique with that of source receiver function method for central part of Indo-Gangetic Plain showed good agreement with our present study.

(3) By correlating deep borehole sediment thickness with resonant frequency, an empirical equation was established for IGP, which is: $H=234.45\left(f_{r}^{-0.69}\right)$, having $R^{2}$ value of 0.8865 . This equation was compared with three other published deep soil site equations. The error in estimation of sediment thickness with these equations was calculated, and based on the poor performance of these equations to predict sediment thickness accurately for the IGP, it was concluded that it would be better to develop region-specific equation for the estimation of sediment thickness for a particular region of interest.

(4) Using the sediment thickness and resonant frequency data from previously published deep soil site studies along with the data from the present study, a combined equation was developed by regression analysis, which is: $H=137.88\left(f_{r}^{-1.174}\right)$ having $R^{2}$ value of 0.8835 . The proposed combined equation can be used for a quick preliminary assessment of the sediment thickness, when no other such equations are available for a particular region.

However, the applicability of the proposed equation in the present study is limited by the borehole data available for IGP. Future research works can be taken up in this regard to find out the applicability of the present equation for the entire Indo-Gangetic basin. Also, other geophysical methods such as multi-channel analysis of surface waves (MASW) can be performed along with microtremor 


\section{RESEARCH ARTICLES}

survey to obtain better estimation of the dynamic properties of subsurface layers of a particular site, since it is also possible to map bedrock using the MASW method, the sediment thickness calculated from both the methods could also be compared.

1. Andrews, D. J., Separation of source and propagation spectra of seven mammoth lakes after-shocks, In Proceedings of Workshop 16 Dynamic characteristics of faulting, 1982, pp. 82591

2. Iwata, T., Separation of source, propagation and site effects from observed S-waves. Zisin, Ser. 2, 1986, 39, 579-593.

3. Çelebi, M., Topographical and geological amplifications determined from strong-motion and aftershock records of the 3 March 1985 Chile earthquake. B. Seismol. Soc. Am., 1987, 77, 11471167.

4. Field, E. H., Hough, S. E. and Jacob, K. H., Using microtremors to assess potential earthquake site response: a case study in Flushing Meadows, New York City. B. Seismol. Soc. Am., 1990, 80, 14561480.

5. Hough, S. E., Seeber, L., Lerner-Lam, A., Armbruster, J. C. and Guo, H., Empirical Green's function analysis of Loma Prieta aftershocks. B. Seismol. Soc. Am., 1991, 81, 1737-1753.

6. Takemura, M., Kato, K., Ikeura, T. and Shima, E., Site amplification of S-waves from strong motion records in special relation to surface geology. J. Phys. Earth, 1991, 39, 537-552.

7. Kato, K., Takemura, M., Ikeura, T., Urao, K. and Uetake, T., Preliminary analysis for evaluation of local site effects from strong motion spectra by an inversion method. J. Phys. Earth, 1992, 40, 175-191.

8. Tai, M., Iwasaki, Y. and Oue, M., Separation of source, propagation and local site effects from accelerographs and its application to predict strong ground motion by summing small events. In Proceedings of the 10th World Conference on Earthquake Engineering, 1992, vol. 2, pp. 747-750

9. Kowada, A., Tai, M., Iwasaki, Y. and Irikura, K., Evaluation of horizontal and vertical strong ground motions using empirical site-specific amplification and phase characteristics. J. Struct. Constr. Eng., 1998, 97-104.

10. Nakamura, Y., A method for dynamic characteristics estimation of subsurface using microtremor on the ground surface. QR Railway Tech. Res. Inst., 1989, 30, 25-33.

11. Paudyal, Y. R., Yatabe, R., Bhandary, N. P. and Dahal, R. K., Basement topography of the Kathmandu Basin using microtremor observation. J. Asian Earth Sci., 2013, 62, 627-637.

12. Field, E. and Jacob, K., The theoretical response of sedimentary layers to ambient seismic noise. Geophys. Res. Lett., 1993, 20, 2925-2928.

13. Lachet, C. and Bard, P. Y., Numerical and theoretical investigations on the possibilities and limitations of Nakamura's technique. J. Phys. Earth, 1994, 42, 377-397.

14. Ibs-von Seht, M. and Wohlenberg, J., Microtremor measurements used to map thickness of soft sediments. B. Seismol. Soc. Am. 1999, 89, 250-259.

15. Bour, M., Fouissac, D., Dominique, P. and Martin, C., On the use of microtremor recordings in seismic microzonation. Soil Dyn. Earthq. Eng., 1998, 17, 465-474.

16. Delgado, J., Casado, C. L., Estevez, A., Giner, J., Cuenca, A. and Molina, S., Mapping soft soils in the Segura river valley (SE Spain): a case study of microtremors as an exploration tool. J. Appl. Geophys., 2000, 45, 19-32.

17. Tuladhar, R., Cuong, N. N. H. and Yamazaki, F., Seismic microzonation of Hanoi, Vietnam using microtremor observations. In 13th world conference on earthquake engineering Vancouver, BC, Canada, 2004, p. 2539.
18. Hasancebi, N. and Ulusay, R., Evaluation of site amplification and site period using different methods for an earthquake-prone settlement in Western Turkey. Eng. Geol., 2006, 87, 85-104.

19. Langston, C. A., Chiu, S. C. C., Lawrence, Z., Bodin, P. and Horton, S., Array observations of microseismic noise and the nature of $H / V$ in the Mississippi embayment. B. Seismol. Soc. Am., 2009, 99, 2893-2911.

20. Mucciarelli, M., Ambient noise measurements following the 2011 Christchurch earthquake: relationships with previous microzonation studies, liquefaction, and nonlinearity. Seismol. Res. Lett., 2011, 82, 919-926.

21. Paudyal, Y. R., Bhandary, N. P. and Yatabe, R., Seismic microzonation of densely populated area of Kathmandu Valley of Nepal using microtremor observations. J. Earthq. Eng., 2012, 16, 12081229.

22. Paudyal, Y. R., Yatabe, R., Bhandary, N. P. and Dahal, R. K., A study of local amplification effect of soil layers on ground motion in the Kathmandu Valley using microtremor analysis. Earthq. Eng. Eng. Vib., 2012, 11, 257-268.

23. Dinesh, B. V., Nair, G. J., Prasad, A. G. V., Nakkeeran, P. V. and Radhakrishna, M. C., Estimation of sedimentary layer shear wave velocity using micro-tremor $H / V$ ratio measurements for Bangalore city. Soil Dyn. Earthq. Eng., 2010, 30, 1377-1382.

24. Sukumaran, P., Parvez, I. A., Sant, D. A., Rangarajan, G. and Krishnan, K., Profiling of late Tertiary-early Quaternary surface in the lower reaches of Narmada valley using microtremors. J. Asian Earth Sci., 2011, 41, 325-334.

25. Natarajan, T. and Rajendran, K., Estimates of site response based on spectral ratio between horizontal and vertical components of ambient vibrations in the source zone of 2001 Bhuj earthquake. J. Asian Earth Sci., 2015, 98, 85-97.

26. Natarajan, T. and Rajendran, K., Site responses based on ambient vibrations and earthquake data: a case study from the meizoseismal area of the 2001 Bhuj earthquake. J. Seismol., 2017, 21, 335347.

27. Sant, D. A., Parvez, I. A., Rangarajan, G., Patel, S. J., Bhatt, M. N. and Salam, T. S., Subsurface profiling along Banni Plains and bounding faults, Kachch, Western India using microtremors method. J. Asian Earth Sci., 2017, 146, 326-336.

28. Joshi, A. U. et al., Subsurface profiling of granite pluton using microtremor method: southern Aravalli, Gujarat, India. Int. J. Earth Sci., 2018, 107, 191-201.

29. Burrard, S. G., On the origin of the Indo-Gangetic trough, commonly called the Himalayan foredeep. Proc. R. Soc. London A, 1915, 91, 220-238.

30. Singh, M., The Gangar River: Fluvial Geomorphology, Sedimentation Processes and Geochemical Studies, Doctoral dissertation, Heidelberg University, 1995.

31. GSI, Seismo-tectonic Atlas of India and its Environs, Geological Survey of India, 2000.

32. Sastri, V. V., Bhandari, L. L., Raju, A. T. R. and Datta, A. K., Tectonic framework and subsurface stratigraphy of the Ganga basin. Geol. Soc. India, 1971, 12, 222-233.

33. Srivatsava, A. B., District resource maps of Geological Survey of India, Kanpur, Uttar Pradesh, India, 2001.

34. Srinivas, D., Srinagesh, D., Chadha, R. K. and Ravi Kumar, M., Sedimentary thickness variations in the Indo-Gangetic foredeep from inversion of receiver functions. B. Seismol. Soc. Am., 2013, 103, 2257-2265.

35. Manglik, A., Adilakshmi, L., Suresh, M. and Thiagarajan, S., Thick sedimentary sequence around Bahraich in the northern part of the central Ganga foreland basin. Tectonophysics, 2015, 653, $33-40$.

36. Konno, K. and Ohmachi, T., Ground-motion characteristics estimated from spectral ratio between horizontal and vertical components of microtremor. B. Seismol. Soc. Am., 1998, 88, 228 241.

CURRENT SCIENCE, VOL. 117, NO. 9, 10 NOVEMBER 2019 
37. SESAME Guideline for the implementation of the $H / V$ spectral ratio technique on ambient vibrations: measurements, processing and interpretation. SESAME European research project, 2004, WP12, pp 1-62.

38. Srinagesh, D., Singh, S. K., Chadha, R. K., Paul, A., Suresh, G., Ordaz, M. and Dattatrayam, R. S., Amplification of seismic waves in the central Indo-Gangetic basin, India. B. Seismol. Soc. Am., 2011, 101, 2231-2242.

39. Parolai, S., Bormann, P. and Milkereit, C., New relationships between $V_{s}$, thickness of sediments, and resonance frequency calculated by the $H / V$ ratio of seismic noise for the Cologne area (Germany). B. Seismol. Soc. Am., 2002, 92, 2521-2527.

40. Hinzen, K. G., Weber, B. and Scherbaum, F., On the resolution of $H / V$ measurements to determine sediment thickness, a case study across a normal fault in the Lower Rhine Embayment, Germany. J. Earthq. Eng., 2004, 8, 909-926.

41. Birgören, G., Özel, O. and Siyahi, B., Bedrock depth mapping of the coast south of Istanbul: comparison of analytical and experimental analyses. Turk. J. Earth Sci., 2009, 18, 315-329.

42. Özalaybey, S., Zor, E., Ergintav, S. and Tapırdamaz, M. C., Investigation of 3-D basin structures in the Izmit Bay area (Turkey) by single-station microtremor and gravimetric methods. Geophys. J. Int., 2011, 186, 883-894.
43. Biswas, R., Baruah, S. and Bora, D. K., Mapping sediment thickness in Shillong City of Northeast India through empirical relationship. J. Earthq., 2015, 572619-1-8.

44. Del Monaco, F., Durante, F., Macerola, L. and Tallini, M., Quaternary sedimentary cover thickness versus seismic noise resonance frequency in Western L' Aquila Plain, 2015; http://www3.ogs.trieste.it/gngts/files/2015/S22/Riassunti/DelMonaco. pdf

45. Khan, S. and Khan, M. A., Mapping sediment thickness of Islamabad city using empirical relationships: Implications for seismic hazard assessment. J. Earth Syst. Sci., 2016, 125, 623-644.

ACKNOWLEDGEMENTS. We thank DST, New Delhi, for financial support. We also thank the Chairman of Centre for Earth Sciences, Indian Institute of Science, Bengaluru, for providing the equipment used in this study.

Received 5 October 2018; re-revised accepted 22 July 2019

doi: $10.18520 / \mathrm{cs} / \mathrm{v} 117 / \mathrm{i} 9 / 1482-1491$ 